option for motivated teachers. Rather than seeking literature or case studies in which integration is already present, Lovenduski shows how a careful teacher may synthesize the feminist and non-feminist approaches within a particular course or module. Lovenduski has, of course, done this in her own research and scholarship; here she shows how any teacher can do this in the classroom. She presents the cases of Britain and former West Germany. A third strategy is presented by Sonja Elison who has incorporated into her classroom some participatory exercises that enrich students perceptions of the importance of gender as a concept in political science. She describes three ways by which students can be drawn into the discussion of women and politics.

Christine Di Stefano provides the viewpoint of a feminist theorist on integrating gender into the general political science curriculum. She differentiates between the concepts of gender, women, and feminism to indicate that while gender and politics research is not necessarily done by individuals with feminist goals, its application in the classroom potentially helps answer the question of how to make democracy more "accessible" and "safe" for women. Di Stefano's essay closes our discussion by placing the concrete act of mainstreaming gender into the broader perspective of theory and practice; hence she provides a roadmap for those who choose to pursue this challenging but worthwhile endeavor.

These articles are not intended to be a critique of political science so much as a practical guide to the challenges, benefits, and pitfalls of introducing gender into political science courses that particularly focus on contemporary Western European politics. They demonstrate some of the drawbacks of using published research in the classroom-although all the authors argue that the drawbacks are outweighed many benefits. The articles also give practical advice on the incorporation of such material, from Eliason's careful case constructed from Scandinavian welfare state literature and Lovenduski's discussion of the case of participation to Elison's hands-on approach. ${ }^{3}$ As Di Stefano suggests, the most important benefit of integration gender into teaching European politics is its impact on our understanding of both the concept and the reality of late twentieth century democracies.

\section{Notes}

1. Thanks go to the Center for West European Studies at the University of Washington, the Meyer Fund at Washington State University, the Division of Governmental Studies and Services and the Department of Political Science/Criminal Justice Program at Washington State University for generous funding. John Keeler's (Director, CWES) encouragement and support as well as Katherine Kittel's (Associate Director) help with making local arrangements were crucial to the success of this project. Leslie Eliason, Christine Di Stefano, Dorothee Wierling and Caroline Weidmar also played key roles in the workshop. Finally, we would like to extend our gratitude to the regional participants who made this workshop truly worthwhile.

2. See Christine Di Stefano's article below for a discussion of definitions of gender.

3. For syllabi collections in Gender and
Politics see Kenney (1996). The CWES at the University of Washington has begun a collection of 'gendered' syllabi across the disciplines in European Studies (for more information, contact John Keeler, Director).

\section{References}

Carroll, Susan J. and Linda M. G. Zerilli. 1993. "Feminist Challenges to Political Science." In The State of the Discipline II, ed. Ada Finifter, 55-76. Washington, DC: APSA.

Kenney, Sally, ed. 1996. A Collection of Syllabi for Courses on Women and Politics. Washington, DC: APSA.

Randall, Vicky. 1991. "Feminism and Political Analysis." Political Studies 39:513-32.

Ross, George. 1995. "Celebrating CES' Birthday." Council for European Studies Newsletter 24(5/6):2-5.

Sapiro, Virginia. 1991. "Gender Politics, Gendered Politics: The State of the Field." In The Theory and Practice of Political Science ed. W. Crotty, Vol. 1. 165-87. Evanston, IL: Northwestern University Press.

\section{About the Authors}

Andrew M. Appleton, department of political science, Washington State University, is the co-editor of State Party Profiles (1996) and co-author of the forthcoming Party Politics. In addition, he has authored several articles and chapters dealing with comparative party organization, party politics, and voting behavior.

Amy G. Mazur is assistant professor of political science at Washington State University. She is author of Gender Bias and the State: Symbolic Reform at Work in Fifth Republic France (1996) and co editor (with Dorothy McBride Stetson) of Comparative State Feminism. Other recent publications include, "The Interplay: The Formation of Sexual Harassment Legislation in France." In European Integration: The New Feminist Challenge. R. Amy Elman, ed. (1996) and "Gender and Party Politics in France." with Andrew Appleton, in Gender and Party Politics, J. Lovenduski and P. Norris, eds. (1993).

\title{
Gender and European Politics: The Limits of Integration
}

\section{Dorothy McBride Stetson, Florida Atlantic University}

An instructor who integrates gender into a course on European politics and society has at least three options: (1) to add a separate section on women; (2) to supplement the material in the text with a specialty reader on gender (such as Loven- duski \& Norris 1993; Kaplan 1992); or (3) to include topical articles on women and politics in a course packet (e.g. Siim 1994; Rule 1987). While these options expose students to information about women and politics, gender issues and relations, and feminist politics in Europe, they do not solidly integrate the study of gender and European politics into the political science curriculum.

The European politics curriculum presently neither embraces gender as an analytical category nor regards it 
as an important object of analysis. Most political scientists with research specialities in European countries continue-like their postwar fathers-to dismiss women and gender as irrelevant to their research. Textbooks reflect the absence of gender topics from research on European politics and policy. Consider most any recent textbook on parties, politics, elections, or policy, and gender issues are at best afterthoughts. Some texts lack even this minimal treatment of gender. Works claiming to be comprehensive often have a fleeting reference to these topics.

The small but growing group of European and U.S. scholars interested in studying gender-related issues is developing a separate body of work. Until recently, their studies were rarely comparative, and their works were often closely linked to the feminist politics of a particular country, limiting usefulness in courses on comparative European politics. The development of such work has been hampered by a dilemma: feminist approaches to political topics are often based on a critical view of the male-dominated power structure. The assumption that women are subject to, but not part of, government makes their place in the study of government peripheral at best. Also, European gender studies often use enlarged definitions of politics that drive scholars to delve into topics usually in the domain of other disciplines, thus separating them further from a more traditional political science focus.

There are, therefore, two bodies of research on European politics: feminist and non-feminist. Each body of work has its theoretical framework that directs researchers to the relevant, interesting, and doable projects. Today, instructors can rely on a plentiful literature allowing the exploration of European politics from either a feminist or non-feminist perspective, but they do not yet have a literature that integrates both.

Because feminist and non feminist bodies of research are based on separate theoretical assumptions and paradigms, their integration will be possible only when a common framework is developed. Creating a common framework requires that scholars understand the framework of the other approach and amend both frameworks to guide the elaboration of questions for inquiry. There is evidence that researchers interested in feminist topics are opening the way for such an interchange. If successful, their work will make gender questions an essential part of research on a wide range of topics. Here are my suggestions for developing the new framework.

\section{Feminist Critiques of the Liberal State}

The feminist critique of the liberal state centers on the assumption that, contrary to myths of democratic theory, the state is not a neutral arbiter of competing interests. Studies of the rise of the liberal state, inspired by the work of Carole Pateman (1988), show the state's foundation in fundamental assumptions of the separation of public from private spheres. Women, relegated to the private sphere by gender role ideologies, were not part of the egalitarian ideology of democratic public life. Despite two waves of feminist movements in European democratic states, women have not overcome this exclusion. From this perspective, no matter how many anti-discrimination laws are passed or how much legislative representation of women is secured, the state will continue to maintain women's subordination.

This critique helps to explain why legal equality in political and civil rights, enjoyed by most European women for over half a century, has not led to equal representation in the arenas of power. Leaders in many countries, appealing to growing gender consciousness in the electorate, have recognized social and cultural barriers to women's participation. Every country with more than token representation in the legislature has some sort of positive discrimination policy or practice, whether quotas or goals. These findings provide some raw material for enriching class discussions of political parties, electoral politics, and representation questions.

There must be more comparative empirical research if the feminist critique of liberal democracy is to be truly synthesized with non-feminist work. A problem with the feminist approach to the state is that it has been part of the debate in the United States over strategies in the feminist movement. European socialist feminists use the critique to argue against the U.S. model of equal rights legislation. The idea that women are excluded from public realms rests on the assumption that male domination is inevitable. But, there is increasing evidence that the presence of more and more women in elected and appointed office has coincided with changes in policies that respond to the demands of various groups of women. This evidence challenges the feminist critique, demonstrates the diversity in women's interests and activities, and raises new questions for comparative study. Are women, with the assistance of quotas, able to gain a stronger foothold on the terrain of the liberal state? Is there not only more participation of women in government, but also a growing gender consciousness? Does the liberal state, with its assumptions of citizen participation, provide options for women to express their demands?

\section{Feminist Critiques of the Welfare State}

Feminist studies of the welfare state have examined the effect of institutional frameworks created through the adoption the wide range of welfare policies. As Leslie Eliason demonstrates in her essay, some of the recent work on the welfare state adapts mainstream conceptual frameworks to feminist projects; such work bridges the gap and helps create an integrated literature. The goal is to take non-feminist frameworks for studying European politics and "infuse" them with gender, through comparative research (Orloff 1993). When regular topics of study always include learning about the gendered aspects of politics, we will have succeeded. 


\section{Comparative State Feminism}

"State feminism" is a concept that originated in studies of the Scandinavian welfare state. Scholars posed their questions regarding policy impact in terms of whether the state, through its policies, can improve the status of women. Australian research has focused more specifically on the special institutions created by government to further the status of women. Amy Mazur and I participate with a group of U.S. and European scholars who study the array of institutions that governments have established to be responsible exclusively with improving the status of women. The objective of this group, the Research Network on Gender, Politics and the State (RNGS), is to determine how these agencies affect the relationship between women and the state.

The RNGS project uses classic comparative methods to study how institutions and processes work to advance the status of women. Our research consists of a conscious effort to integrate feminist and nonfeminist frameworks and methods for studying European politics. Our work is grounded in the recent nonfeminist literature on the state (e.g. Skocpol 1985) and on recent feminist work on conceptions of the state, work that defines the state not as an autonomous entity, but as a collection of sites and arenas (Pringle and Watson 1992). The first stage of this research shows evidence that European states have worked to realize feminist goals, albeit to varying degrees, through the addition of specialized policy machinery (Mazur and Stetson 1995). As it stands, the comparative case studies would be useful to incorporate into a course on comparative policy in either political science or women's studies because the framework includes concepts, definitions, and assumptions linking both sides of the divide.

\section{Democratization and Gender}

The study of gender relations in politics and policy reveals that de- spite decades of equal political rights, women still have less political power than men and are less likely to participate in the decision-making process. At the same time, the conflicts derived from gender relationships have grown. Some maintain that the greatest social change of the twentieth century is the feminization of the work force, which increased gender consciousness among citizens and political actors. Political groups promoting a gender-specific agenda have successfully fomented gender conflicts, which for decades had remained private, in the public arenas. Students of democratization generally agree that it takes more than legal rights to make democracies really work. Rather, it is the institutions and processes of decision-making-related to the processes of recruitment and election-that are the hallmark of democracy. Feminists have compared the representation of women to men in institutions and processes of decision-making in the so-called stable European democracies. They have concluded that the work of building democracy is still underway in Belgium, Britain, France, Germany, Ireland, Italy, the Netherlands, Sweden, Norway, Denmark, Austria, Spain, Portugal, and Greece.

Non-feminist democratization literature helps us examine how states respond to the expansion of gender conflict and the rise in gender consciousness. This helps us to understand better the relationship between society and state institutions and allows us to compare the hierarchy of conflicts in society with the hierarchy in state institutions. It quickly becomes evident that understanding gender is essential to a thorough analysis of European democracies. Asking questions about gender representation through non-feminist democratic frameworks reformulates old concepts making them more useful in studying contemporary politics. It also has the potential of producing an integrated research base necessary for the effective integration of gender into the study of European politics in university curricula.

\section{References}

Kaplan, Gisela. 1992. Contemporary Western European Feminism. New York: New York University Press.

Lovenduski, Joni, and Pippa Norris, eds. 1993. Gender and Party Politics. London: Sage Publications.

Mazur, Amy G. and Dorothy McBride Stetson. 1995. "Conclusion: The Case for State Feminism." In Comparative State Feminism, eds. Stetson and Mazur, 272-92. Newbury Park, CA: Sage.

Orloff, Ann Shola. 1993. "Gender and the Social Rights of Citizenship: The Comparative Analysis of Gender Relations and Welfare States." American Sociological Review 58 (June):303-28.

Pateman, Carol. 1988. The Sexual Contract. Stanford: Stanford University Press.

Pringle, Rosemary, and Sophie Watson. 1992. "Women's Interests' and the Post-Structuralist State." In Destabilizing Theory: Contemporany Feminist Debates, eds. Michele Barrett and Anne Phillips, 52-73. Stanford, CA: Stanford University Press.

Rule, Wilma. 1987. "Electoral Systems, Contextual Factors and Women's Opportunity for Election to Parliament in Twenty-three Democracies." Western Political Quarterly 40:477-98.

Sainsbury, Diane, ed. 1994. Gendering Welfare States. Thousand Oaks, CA: Sage.

Siim, Birte. 1994. "Engendering Democracy: Social Citizenship and Political Participation for Women in Scandinavia." Social Politics 1 (Fall):286-305.

Skocpol, Theda. 1985. "Bringing the State Back In: Strategies of Analysis in Current Research." In Bringing the State Back In, eds. Peter B. Evans, Dietrich Rueschemeyer, and Theda Skocpol, 3-37, Cambridge, MA: Cambridge University Press.

Stetson, Dorothy McBride, and Amy G. Mazur, eds. 1995. Comparative State Feminism. Thousand Oaks, CA.: Sage Publications.

\footnotetext{
About the Author

Dorothy McBride Stetson is professor of political science at Florida Atlantic University. A specialist in the comparative study of women and public policy, she is the author of three books: $A$ Woman's Issue; the Politics of Family Reform in England (1982); Women's Rights in France (1987); and Women's Rights in the U.S.A. (1991; second ed., 1997) and numerous articles and conference papers. Comparative Abortion Policy edited with Marianne Githens, was published in 1996 and Comparative State Feminism edited with Amy G. Mazur was published in 1995. She is a founding member of the Women and Politics Section of the American Political Science Association.
} 